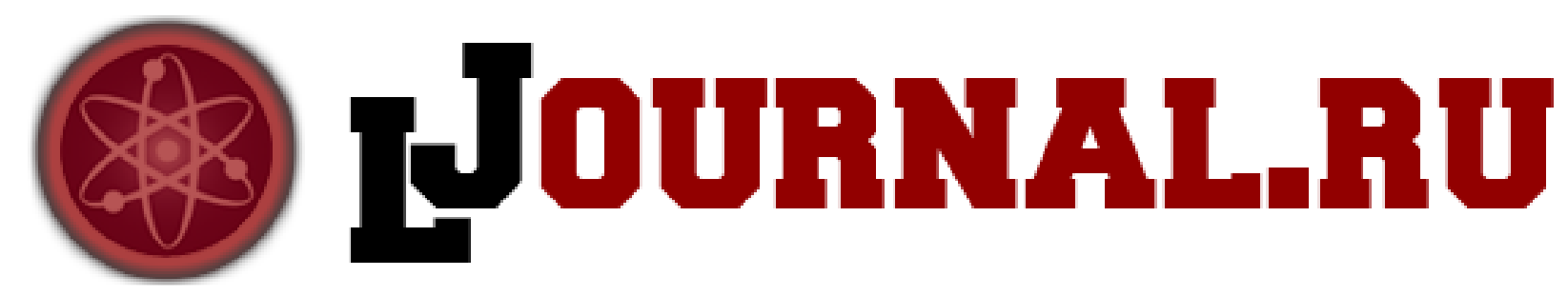

Попова Т.А., Пшеничников И.А., Примачева Н.В., Вечеркина Ж.В. Воронежский государственный медиџинский университет им. Н.Н. Бурденко Россия, Воронеж

doi: $10.18411 / 1 \mathrm{j} 2016-2-20$

\title{
Сравнительная характеристика различных методов снятия зубных отложений
}

Заболевания тканей пародонта являются одной из важнейших проблем в стоматологической практике, поскольку характеризуются высоким уровнем распространенности среди населения, тяжестью течения и негативным влиянием на общее состояние организма и качество жизни человека [2].

Это явилось обоснованием для разработки и внедрении в стоматологическую практику программы профилактики воспалительных заболеваний пародонта (ВЗП), включающей в себя 2 звена: первичную и вторичную профилактику.

Под первичной профилактикой подразумевается система мероприятий, направленных на предупреждение патологии пародонта путем устранения факторов риска и повышения уровня здоровья пациентов.

Под вторичной профилактикой заболеваний пародонта подразумевается комплекс мероприятий, направленных на поддержание или улучшение состояния, достигнутого в процессе лечения ранних стадий заболевания пародонта и предупреждение их прогрессирования.

Одним из важнейших этапов первичной и вторичной профилактики воспалительных заболеваний пародонта является профессиональная гигиена 
полости рта. В настоящее время в пародонтологии используются различные методы снятия зубных отложений [1], но данных по их влиянию на состояние твердых тканей зуба в литературе невелико и часто они носят противоречивый характер.

В связи с этим, целью нашего исследования явилось проведение сравнительной характеристики различных методов снятия зубных отложений.

Материал и методы исследования.

Материалом для изучения in vitro послужили 32 удаленных по медицинским показаниям зубов. Снятие зубных отложений проводилось при помощи:

1) кюрет Грейси. Кюреты Грейси изготовляются из высокопрочной стали. Для эффективной работы их режущий край расположен под идеальным углом к поверхности зуба,. Этот угол обеспечивает возможность работы инструментом в таких специфических участках поверхности зуба, как биили трифуркация или глубокие поверхности корня.

2) магнитостриктивного скейлера (установка Chirana, Чехия, частота 25 кГц)

3) пьезоэлектрического аппарата Piezon-Master 600 (EMS, Switzerland, частота 32 кГц)

4) аппарата «Vector» («Durr Dental», Германия, частота 25 кГц).

Используемое оборудование: растровый электронный микроскоп «CamScan S4».

Использование именно растровой электронной микроскопии (РЭМ) для изучения твердых тканей зуба было обусловлено ее высокой разрешающей способностью (увеличение х 200-5000 раз), а также возможностью исследовать без сложной предварительной подготовки образцы с произвольной геометрией и получать информацию о пространственном расположении микроструктур в объекте)

\section{Результаты исследования}


По данным РЭМ, при снятии зубных отложений с помощью кюрет Грейси на поверхности цемента корня и пришеечной эмали остается достаточное количество зубных отложений, в связи с чем поверхность зубов на электроннограммах выглядит «загрязненной», а структурный рисунок цемента и эмали не отчетлив. На поверхности эмали в пришеечной области наблюдаются линейные повреждения пелликулы, являющиеся «царапинами» от действия острых кюрет. При использовании кюрет Грейси также происходит снятие поверхностного слоя цемента корня, вследствие чего нарушается его структурный рельеф.

На электроннограммах зубов (по данным РЭМ), обработанных магнитостриктивным скейлером, отмечается практически полное удаление зубных отложений. Поверхность цемента корня и эмали в области шейки зуба выглядит почти чистой от зубных отложений. На эмали зубов определяются участки как совершенно гладкие, так и несколько шероховатые, то есть формируется иррегулярная поверхность. Поверхностная структура цемента корня практически не нарушена.

При работе пьезоэлектрическим скейлером аппаратом Piezon-Master 600 наблюдается (по данным РЭМ) более качественное снятие зубных отложений. Поверхностная структура эмали и цемента корня при этом не нарушена. На некоторых участках поверхности эмали хорошо определяются контуры эмалевых призм. Поверхность цемента корня на электроннограммах идентична поверхностному рельефу интактного цемента.

На электроннограммах зубов (по данным РЭМ), обработанных аппаратом «Vector», также определяется качественное снятие зубных отложений. При этом на поверхности пришеечной эмали и цемента корня зуба образуется пленка из твердого вещества, образованного частицами (размером 10 микрон) мелкодисперсной суспензии гидроксиаппатита «Vector Fluid Polish». В ряде участках данная пленка имеет трещины, в связи с высыханием препарата после 
проведенной лечебной манипуляции.

Образование пленки из частиц гидроксиаппатита на поверхностном рельефе эмали и цемента благотворно влияет на их жизнедеятельность. Это находит подтверждение в клиническом снижении гиперчувствительности зубов после снятия зубных отложений.

Данная пленка сохраняется и через 1 неделю после лечебных манипуляций (при исследовании in vitro) как на поверхности пришеечной эмали, заполняя в том числе и ряд эмалевых отверстий, так и на цементе корня зуба, что имеет важное значение для обменных процессов твердых тканей зуба.

Таким образом, максимально негативные изменения в твердых тканях зуба из рассмотренных способов снятия зубных отложений выявляются при работе кюретами Грейси.

А наименьшие нарушения микроструктуры твердых тканей зуба наряду с качественным снятием зубных отложений наблюдаются при использовании как аппарата Piezon-Master 600, так и особенно аппарата «Vector».

Кроме того, малоинвазивность работы аппаратом «Vector» наряду с позитивным воздействием частиц гидроксиаппатита способствуют созданию оптимального биологического состояния для твердых тканей зуба.

\section{Вывод}

Следовательно, при проведении как первичной, так и вторичной профилактики воспалительных заболеваний пародонта наиболее эффективны ультразвуковые методы снятия зубных отложений. Причем применение аппарата «Vector» предпочтительно как при проведении индивидуальной профилактики воспалительных заболеваний пародонта, так и на этапе поддерживающей терапии. 
TA Popova, IA Pshenichnikov, NV Primacheva, JV Vecherkina Voronezh State Medical University. NN Burdenko,

Voronezh, Russia

Comparative characteristics of various methods of removing dental plaque

The paper deals with the comparative characteristics of various methods of removing dental plaque in the prevention of periodontal inflammatory diseases.

\section{Литература:}

1. Влияние различных способов снятия зубных отложений на микроструктуру твердых тканей зуба / А.А. Кунин [и др.] // Пародонтология, 2010, Т. XV, № 2 (55), C. 33-36.

2. Пропедевтика хирургической стоматологии / А.Н. Морозов [и др.] // Международный журнал прикладных и фундаментальных исследований, Москва, № 3, Ч. 2, 2014, С. 158-159. 